\title{
PERINTISAN KAMPUNG HIJAU DESA KEBONAGUNG UNTUK EDUKASI, LUMBUNG TOGA, DAN UMKM
}

\author{
Elana Era Yusdita*1, Ambarwati², Muhammad Jazuli Yusuf ${ }^{3}$ \\ 1 Program Studi Pendidikan Akuntansi, Fakultas Keguruan dan Ilmu Pendidikan, Universitas PGRI Madiun \\ 2,3Program Studi Akuntansi, Fakultas Ekonomi dan Bisnis, Universitas PGRI Madiun \\ *e-mail: elaradita@gmail.com¹, Ambarwaty76@gmail.com²,mjazuliyusuf98@gmail.com³
}

\begin{abstract}
This service activity aims to pioneer a green village in Kebonagung Village, Mejayan District, Madiun Regency. This green village is expected to be useful as an educational garden regarding the scientific name of plants for early childhood, kindergarten and elementary school children who during the pandemic have to go to school from their respective homes. In addition, medicinal plants are expected to be useful for the community to maintain the body's immune system during a pandemic, and ornamental plants can be developed into MSME businesses. The service stages carried out include the provision of facilities and infrastructure from the donation, mapping green village land, planting, and naming roads and plants. The community feels that this program is in accordance with the ideals of a green village-based tourism village, but it still needs assistance.
\end{abstract}

Keywords: green village; educational park; granary of medicinal plants; ornamental plant business; tourism village

\begin{abstract}
Abstrak
Kegiatan pengabdian ini bertujuan untuk merintis kampung hijau di Desa Kebonagung, Kecamatan Mejayan, Kabupaten Madiun. Kampung hijau ini diharapkan bermanfaat sebagai kebun edukasi mengenai nama ilmiah tanaman bagi anak PAUD, TK, dan SD yang selama pandemi harus bersekolah dari rumah masing-masing. Selain itu, tanaman obat diharapkan dapat bermanfaat bagi masyarakat untuk menjaga sistem imun tubuh selama pandemic, serta tanaman hias dapat dikembangkan menjadi bisnis UMKM. Tahapan pengabdian yang terlaksana meliputi pengadaan sarana dan prasarana dari hasil donasi, pemetaan lahan kampung hijau, penanaman, dan penamaan jalan serta tanaman. Masyarakat merasa program ini sesuai dengan cita-cita kampung wisata berbasis kampung hijau,namun masih memerlukan pendampingan.
\end{abstract}

Kata kunci: kampung hijau; taman edukasi; lumbung tanaman obat; bisnis tanaman hias; kampung wisata

\section{PENDAHULUAN}

Selama wabah covid-19, new normal mengharuskan masyarakat mengubah kebiasaan hidup mereka. Selain perilaku hidup sehat dan bersih melalui 5M, mereka yang terbiasa kerja kantoran terpaksa harus bekerja dari rumah, bahkan yang tidak bisa mengonversi kegiatan mereka menjadi pekerja rumahan harus berhenti bekerja. Sebagian lagi harus mengalami pemutusan hubungan kerja karena daya beli masyarakat berkurang selama pandemi covid-19 dan tempat bekerja mereka tidak dapat menyesuaikan kondisi selama pandemi. Siswa dan mahasiswa pun terdampak dari yang semula belajar luring, kini harus belajar dari rumah.

Pada sisi yang berlainan, ada beberapa hal yang bertumbuh ke arah positif selama pandemi, antara lain kesadaran penggunaan bahan herbal untuk mencegah terjangkit virus covid-19 melalui peningkatan daya tahan tubuh. Hal ini berimbas kepada meningkatnya 
permintaan jamu dan pasokan bahan mentahnya yang mencapai 2 kali lipat (Anonim, 2020). Masyarakat juga mulai menghidupkan taman TOGA di kampung masing-masing. Hal kedua yang dirasa meningkat popularitasnya adalah tanaman hias untuk mengisi waktu luang selama tetap di rumah. Baik toko luring maupun daring mengalami kenaikan hingga 10 kali lipat (Lidyana, 2020).

Kebonagung merupakan salah satu desa di Kecamatan Mejayan, Kabupaten Madiun yang memiliki potensi alam berupa sawah berundak dan lingkungan yang masih asri, dimana $44,2 \%$ lahannya berupa tanah sawah. Selain itu, warga desa memanfaatkan lahan untuk perkebunan yang mayoritas menghasilkan mangga, sedangkan untuk tanaman apotik hidup dan semacamnya belum ada. Mengingat potensi tanahnya yang subur namun belum beragamnya jenis tanaman yang ditanam oleh masyarakat, serta menjawab tantangan menciptakan desa tangguh secara ekonomi, kesehatan, dan pendidikan, maka tim pengabdian masyarakat memutuskan untuk merintis kampung hijau yang mengintegrasikan ketiga tujuan tersebut. Cita-cita mendirikan kampung hijau memang sudah ada sejak lama, namun kelurahan beserta pemuda karang taruna belum bisa mewujudkan karena belum terkonsep secara apik.

Pengabdian terdahulu berkenaan dengan kampung hijau sudah banyak dilakukan, misalnya Kavling Melati RW 06 Kelurahan Sungai Pelunggut, Riau yang memulai penanaman 1000 pohon di unit lingkungan terkecil untuk mengatasi banjir (Yanizon \& Rofiqah, 2018), edukasi perintisan kebun bibit di Desa Panggulo Barat, Provinsi Gorontalo untuk mengatasi kualitas rendah hasil panen pada lahan tandus (Angelia, 2019), penyadaran masyarakat tentang ruang terbuka hijau di Kelurahan Meruya Selatan, Jakarta (Ischak \& Burhannudinnur, 2020) dan Kampung Tanjung Gedong di Jakarta Barat (Solikhah \& Fatimah, 2020), sedangkan gerakan kampung hijau di Cempaka Putih, Jakarta Pusat berfokus pada pemilahan sampah organik dan non organik (Aziz, Setiawan \& Hikmawan, 2020).

Perbedaan kegiatan pengabdian masyarakat kali ini adalah berfokus kepada pengoptimalan ruang terbuka hijau yang sudah ada untuk meminimalkan dampak covid-19, yaitu pengenalan nama tanaman latin dan Bahasa Indonesia untuk sarana edukasi anak yang belum dapat bersekolah secara luring, penanaman tanaman obat untuk persediaan herbal dalam meningkatkan daya tahan tubuh, serta pembudidayaan tanaman hias untuk memperindah lingkungan sekaligus perintisan bisnis tanaman hias yang meroket selama covid-19. Semua kegiatan juga dilakukan menggunakan protokol kesehatan untuk mencegah penyebaran covid-19.

\section{METODE}

Kegiatan pengabdian ini bertujuan untuk merintis kampung hijau karena proses menciptakan kampung hijau yang ideal akan memakan waktu yang sangat lama. Dari seluruh rangkaian pada Gambar 1, kegiatan kali ini berada di tahap I. Pengabdian ini berlangsung selama kurang lebih 60 hari saja karena memanfaatkan liburan semester untuk sosialisasi, pendampingan sampai dengan monitoring program. Rangkaian kegiatan ada pada Gambar 2. Waktu pengabdian berlangsung dari tanggal 17 Desember 2020 sampai dengan 17 Februari 2021. Kegiatan berlangsung di Desa Kebonagung, Kecamatan Mejayan, Kabupaten Madiun, Jawa Timur. Lokasi kampung hijau ada pada dua jalan yang membentuk huruf $U$ di desa tersebut. 
Partner utama kegiatan ini adalah Pemerintah Desa Kebonagung dan Karang Taruna RT 10 Dusun Gonalan Desa Kebonagung Kecamatan Mejayan Kabupaten Madiun. Selain itu, ada beberapa pihak yang turut mendonasikan bibit pada program ini, yaitu Dinas Lingkungan Hidup Kabupaten Madiun, Balai Pengelolaan DAS dan Hutan Lindung Solo, serta masyarakat umum.

Kebermanfaatan pengabdian diukur menggunakan kuesioner sederhana dengan item pertanyaan: (1) kegiatan ini bermanfaat untuk masyarakat; (2) kegiatan ini cocok dengan kebutuhan masyarakat; (3) program ini dapat dilanjutkan secara mandiri oleh masyarakat; menggunakan 7 skala Likert dari sangat tidak setuju sampai dengan sangat setuju. Kuesioner sederhana ini disebarkan kepada Lurah Kebonagung, dua orang kamituwo, dua orang perwakilan karang taruna, lima orang perwakilan warga. Total ada 10 orang responden.

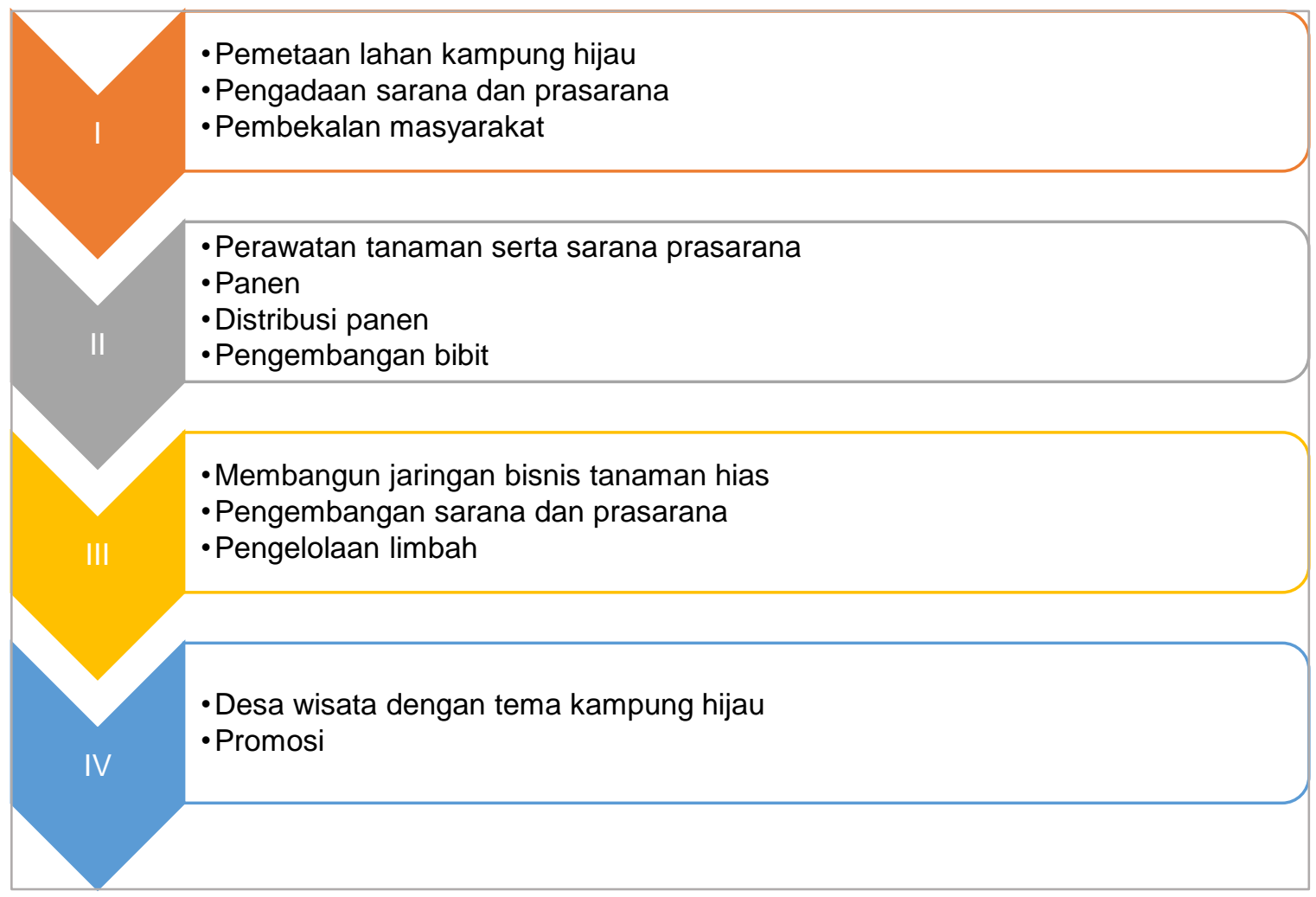

Gambar 1. Tahapan Pengembangan Kampung Hijau 


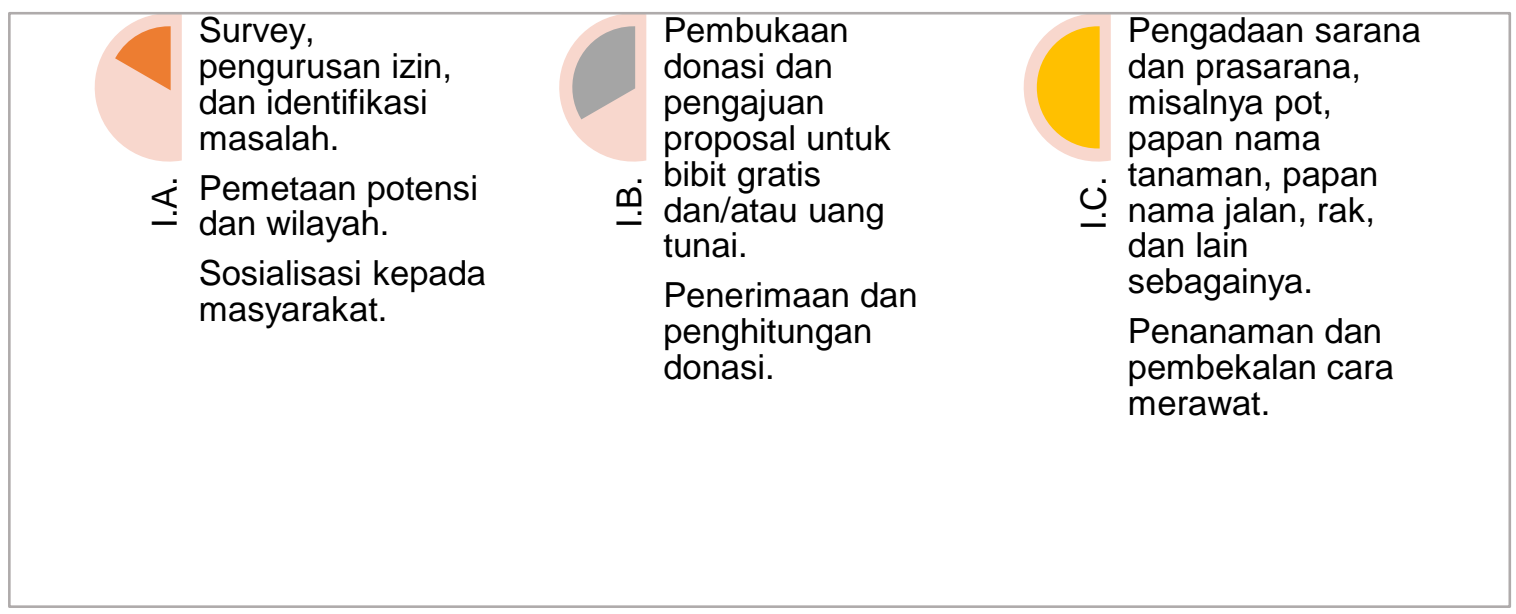

Gambar 2. Tahapan Pelaksanaan Kegiatan Pengabdian Masyarakat

\section{HASIL DAN PEMBAHASAN}

Kegiatan pengabdian secara detil meliputi koordinasi dengan pihak-pihak terkait, persiapan bahan dan persiapan waktu pelaksanan adapun kegiatan persiapan yang dilakukan antara lain sebagai berikut:

1. Melakukan koordinasi pengabdian. Kegiatan rapat kordinasi tim dilakukan pada tanggal 24 Desember 2020. Rapat dihadiri oleh seluruh anggota tim dan perangkat desa Kebonagung. Rapat ini bertujuan untuk menyepakati mengenai waktu dan tempat pelaksanaan kegiatan serta hal-hal lain.

2. Mengadakan pertemuan dengan perangkat desa dan karang taruna serta masyarakat setempat guna membahas kegiatan penghijauan lingkungan, serta memberikan pengetahuan dan pemahaman mengenai pentingnya menjaga lingkungan serta manfaat dari penanaman pohon. Pertemuan ini sudah dilakukan seminggu sebelumnya.

3. Melakukan observasi di lingkungan Dusun Gondalan RT 10 guna menentukan titik lokasi penanaman pohon.

4. Bersama dengan karang taruna dan masyarakat RT 10 menentukan jenis tanaman yang sesuai dengan kondisi lahan

5. Persiapan bahan dan alat. Persiapan pokok pohon yang akan ditanam di wilayah RT10 dan alat-alat yang akan digunakan untuk penanaman pohon. Alat-alat berupa cangkul, sekop, dan semacamnya memanfaatkan milik warga setempat.

6. Persiapan administrasi, meliputi pembuatan izin pelaksanaan ke instansi pemerintah terkait. Pembuatan spanduk dan daftar hadir tim pengabdian juga dilakukan pada tahapan ini.

7. Melakukan penggalangan atau mencari sponsor dana untuk membuat program tersebut. Hasil donasi akan diuraikan di bagian selanjutnya.

8. Pelaksanaan penanaman dan perawatan awal.

9. Monitoring dan evaluasi dengan kuesioner dan observasi.

Berikut dokumentasi beberapa kegiatan: 


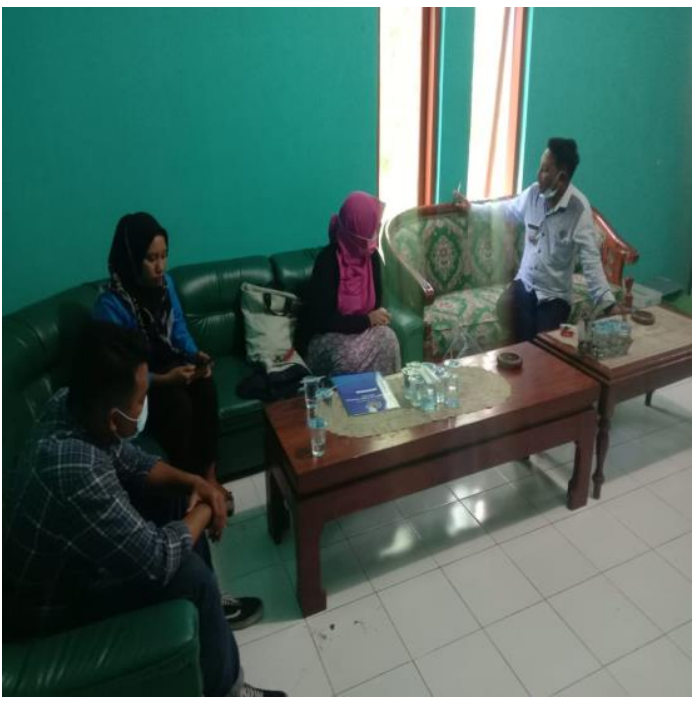

(a)

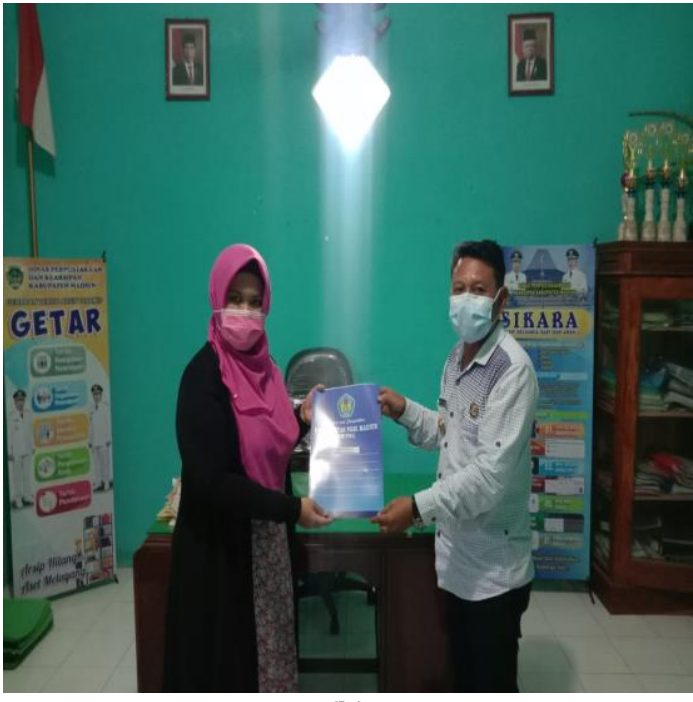

(b)

Gambar 3(a) Koordinasi dan (b) permintaan izin kepada Lurah Kebonagung

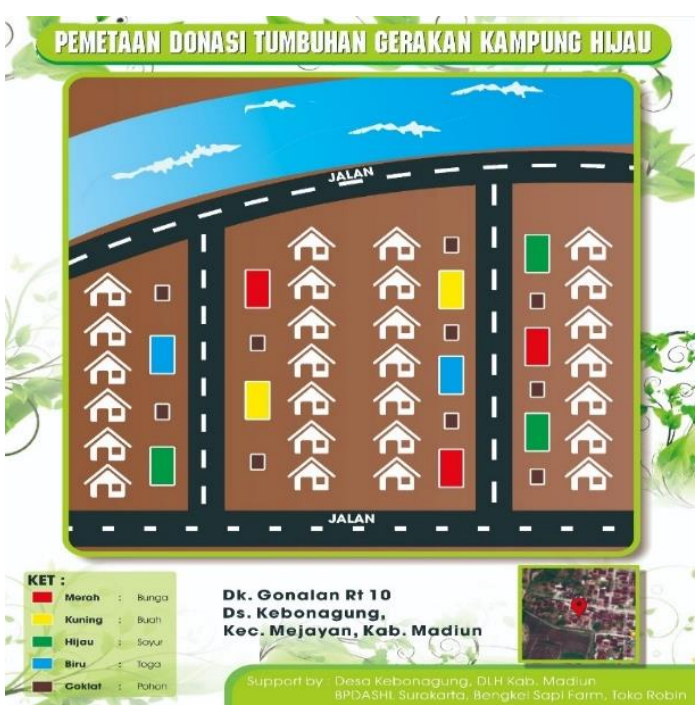

(a)

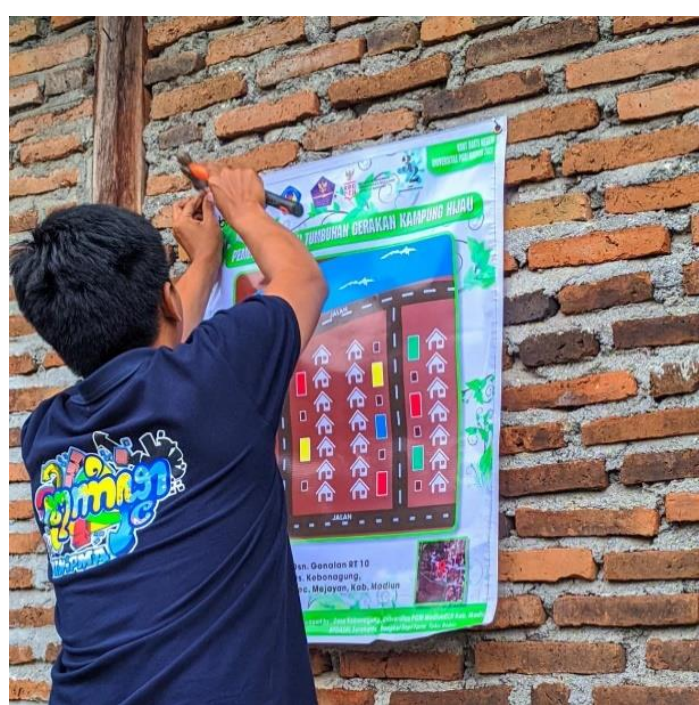

(b)

Gambar 4 (a) Hasil pemetaan kampung hijau dan (b) pemasangan banner peta kampung hijau di Desa Kebonagung 


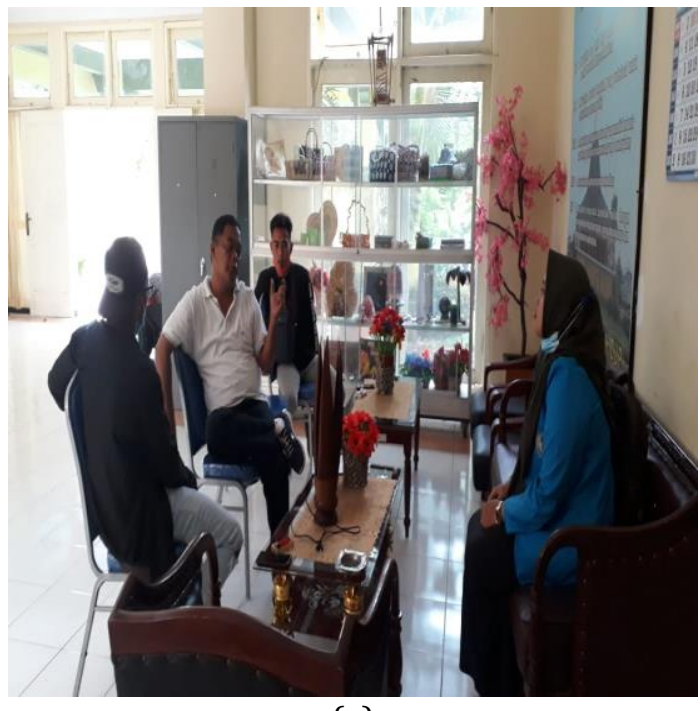

(a)

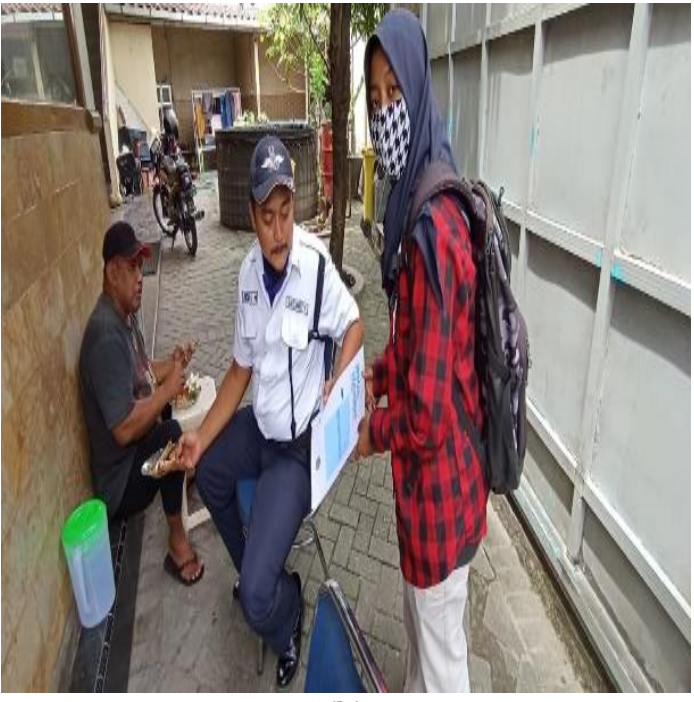

(b)

Gambar 5 (a,b) Pengajuan proposal donasi untuk bibit dan uang

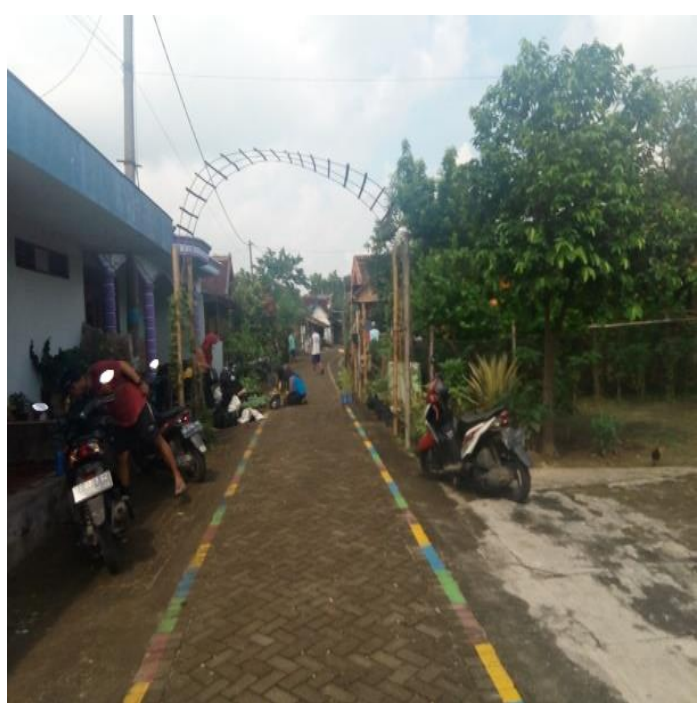

Gambar 6. Salah satu jalan untuk perintisan kampung hijau

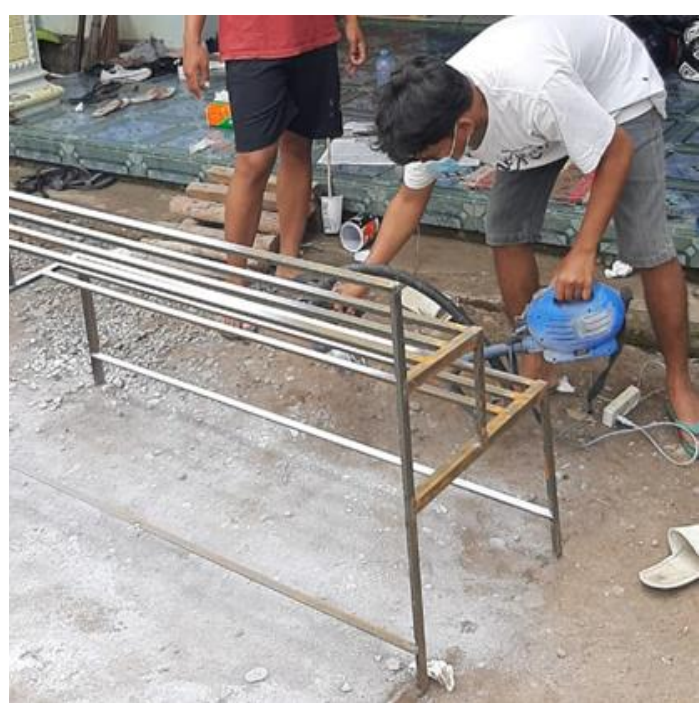

Gambar 7. Pembuatan rak tanaman 


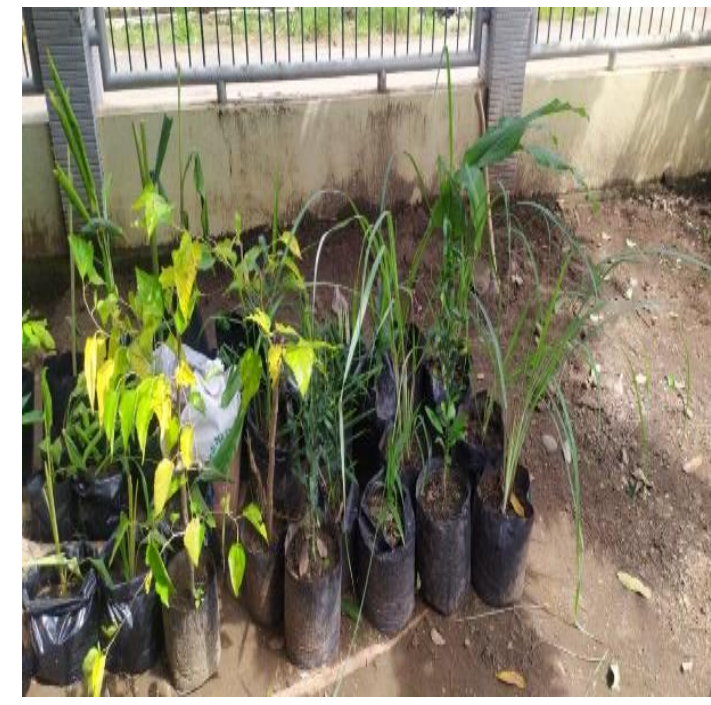

Gambar 8. Donasi berupa bibit untuk lumbung TOGA

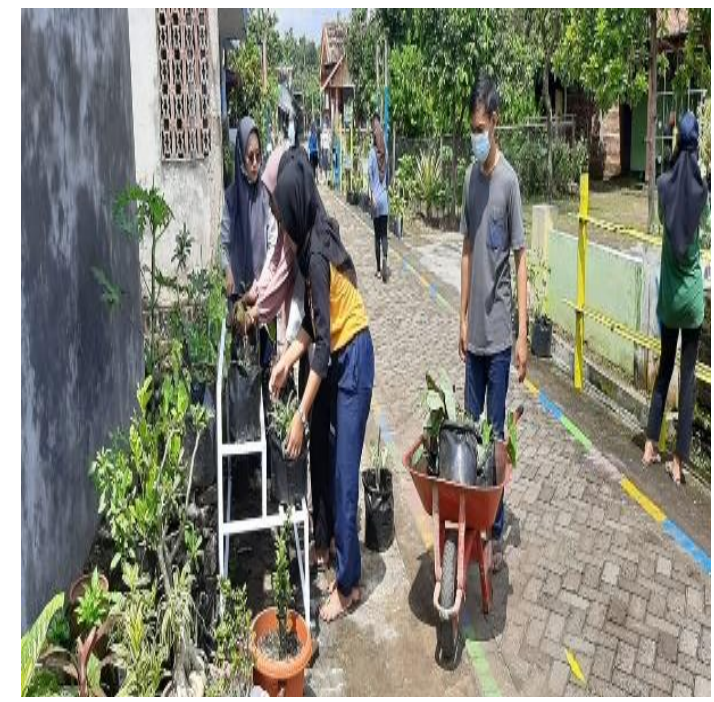

Gambar 10. Penataan tanaman hias di sepanjang jalan lokasi.

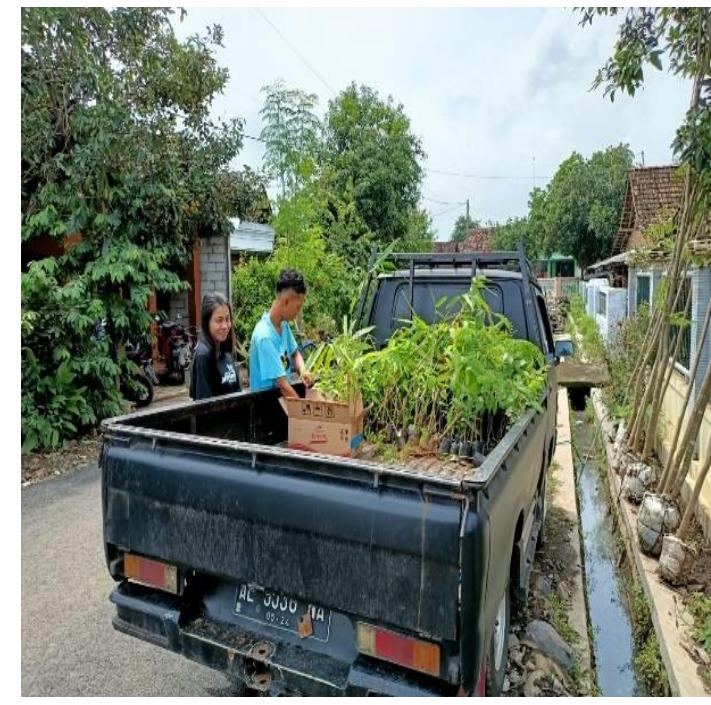

Gambar 9. Donasi berupa bibit tanaman sayur dan buah

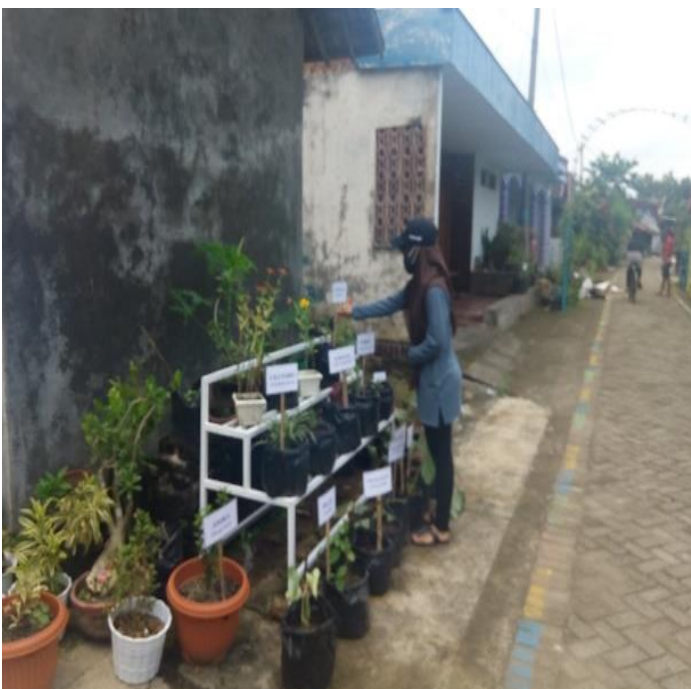

Gambar 11. Pemberian nama tanaman sebagai sarana edukasi anak PAUD, TK, dan SD yang selama pandemi bersekolah dari rumah.

Penyebaran proposal ke beberapa instansi dan tempat usaha membuahkan hasil. Bahkan ada beberapa donasi dari masyarakat umum. Pendapatan donasi berupa uang dialokasikan untuk pengadaan rak tanaman, papan nama jalan, papan tanaman, serta pot. Hasil donasi berupa tanaman dan uang yang didapatkan oleh tim pengabdian ada pada Tabel 1.

Tabel 1. Pendapatan Donasi (Dalam Unit Tanaman dan Rupiah)

\begin{tabular}{llllr}
\hline Nomor & Nama Sponsor & Jenis Donasi & Jumlah & \multicolumn{2}{c}{ Sub total } \\
\hline 1 & DLH & Jakaranda & 10 & 10 \\
2 & PBDASHL & Alpukat & 25 & 260 \\
\hline
\end{tabular}




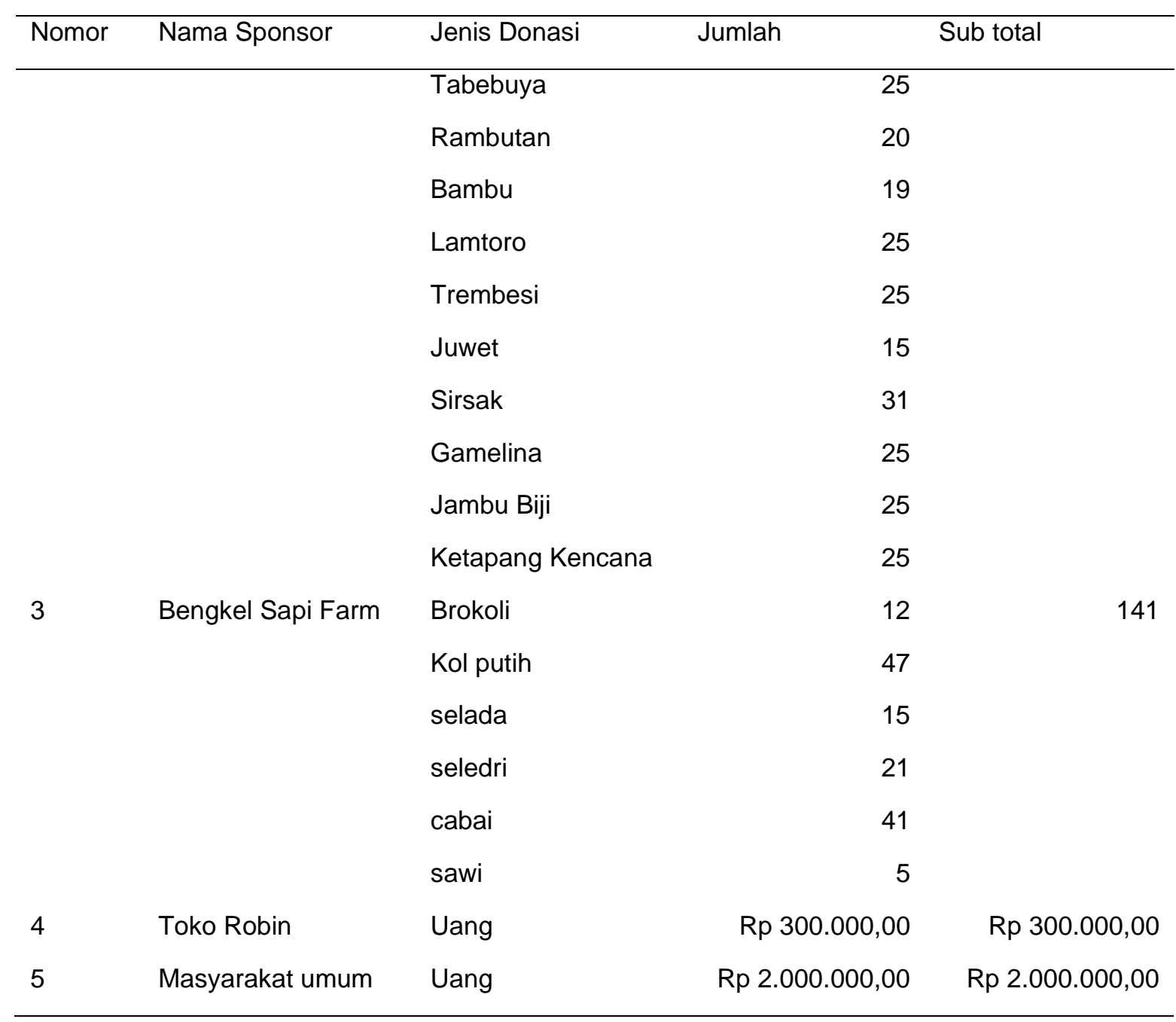

Masyarakat ikut serta dalam pembangunan kampung hijau berupa tenaga. Pengelolaan dan pengawasan setelah tanaman selesai ditempatkan sesuai peta diserahkan kepada pemuda Karang Taruna RT 10 Desa Gonalan. Sedangkan perawatannya akan dilakukan oleh warga di sepanjang jalan lokasi kampung hijau tersebut. Hasil kuesioner pengabdian masyarakat yang disebarkan kepada 10 orang ada pada Tabel 2 .

Tabel 2. Hasil kusioner pengabdian masyarakat di Desa Kebonagung

\begin{tabular}{cccccccccc}
\hline No & $\begin{array}{c}\text { Item } \\
\text { Kuesioner }\end{array}$ & $\begin{array}{c}\text { Sangat } \\
\text { Tidak } \\
\text { Setuju } \\
(1)\end{array}$ & $\begin{array}{c}\text { Tidak } \\
\text { Setuju } \\
(2)\end{array}$ & $\begin{array}{c}\text { Agak } \\
\text { Tidak } \\
\text { Setuju } \\
(3)\end{array}$ & $\begin{array}{c}\text { Netral } \\
(4)\end{array}$ & $\begin{array}{c}\text { Agak } \\
\text { Setuju } \\
(5)\end{array}$ & $\begin{array}{c}\text { Setuju } \\
(6)\end{array}$ & $\begin{array}{c}\text { Sangat } \\
\text { Setuju } \\
(7)\end{array}$ & $\begin{array}{c}\text { Skor } x \\
\text { Jumlah } \\
\text { Responden }\end{array}$ \\
\hline 1 & 0 & 0 & 0 & 0 & 0 & 5 & 5 & 65 \\
\hline $\begin{array}{l}\text { Kegiatan ini } \\
\text { bermanfaat } \\
\text { untuk }\end{array}$ & & & 0 & 0 & 0 & 0 & 4 & 6 & 66 \\
$\begin{array}{l}\text { masyarakat } \\
\text { Kegiatan ini } \\
\text { cocok dengan } \\
\text { kebutuhan } \\
\text { masyarakat }\end{array}$ & 0 & 0 & & & & & & \\
\hline
\end{tabular}




\begin{tabular}{llcccccccc}
\hline No & $\begin{array}{c}\text { Item } \\
\text { Kuesioner }\end{array}$ & $\begin{array}{c}\text { Sangat } \\
\text { Tidak } \\
\text { Setuju } \\
(1)\end{array}$ & $\begin{array}{c}\text { Tidak } \\
\text { Setuju } \\
(2)\end{array}$ & $\begin{array}{c}\text { Agak } \\
\text { Tidak } \\
\text { Setuju } \\
(3)\end{array}$ & $\begin{array}{c}\text { Netral } \\
(4)\end{array}$ & $\begin{array}{c}\text { Agak } \\
\text { Setuju } \\
(5)\end{array}$ & $\begin{array}{c}\text { Setuju } \\
(6)\end{array}$ & $\begin{array}{c}\text { Sangat } \\
\text { Setuju } \\
(7)\end{array}$ & $\begin{array}{c}\text { Skor x } \\
\text { Jumlah } \\
\text { Responden }\end{array}$ \\
\hline 3 & $\begin{array}{l}\text { Program ini } \\
\text { dapat } \\
\text { dilanjutkan } \\
\text { secara } \\
\text { mandiri oleh } \\
\text { masyarakat }\end{array}$ & 0 & 0 & 0 & 0 & 3 & 4 & 2 & 53 \\
\hline
\end{tabular}

Hasil kuesioner menunjukkan rupanya masyarakat masih ragu meneruskan program ini tanpa pendampingan. Padahal untuk jangka panjangnya, kampung hijau ini diharapkan dapat menjadi salah satu destinasi wisata di Kabupaten Madiun. Otomatis kemandirian masyarakat diharapkan meningkat karena ke depannya pengelolaan ini berbasis dari dan untuk masyarakat. Peran aktif anak muda diharapkan lebih untuk menjaga kampung hijau yang telah dirintis. Edukasi tanaman untuk anak-anak, pembibitan lumbung tanaman obat keluarga (TOGA) dan tanaman hias sudah berhasil dilaksanakan. Selebihnya donasi berupa pohon rindang diharapkan dapat menambah keasrian desa Kebonagung.

\section{KESIMPULAN}

Program pengabdian masyarakat untuk merintis kampung hijau di Desa Kebonagung, Kecamatan Mejayan, Kabupaten Madiun telah terlaksana dengan baik. Bahan didapatkan dari donasi dan pelaksanaan melibatkan masyarakat setempat. Kampung hijau tahap awal ini dapat digunakan untuk sarana edukasi anak-anak tentang tanaman, masyarakat juga dapat memanfaatkan hasil tanaman TOGA untuk menjaga sistem imun tubuh selama covid-19, serta pembiakan tanaman hias sebagai perintisan UMKM. Ketiga hal ini menjawab peluang dan tantangan selama pandemic covid-19 serta cita-cita masyarakat Kebonagung untuk desa wisata berbasis kampung hijau. Kegiatan ini diharapkan berkesinambungan baik dari masyarakat maupun pengabdian selanjutnya. Masyarakat merasa kegiatan ini bermanfaat namun masih belum bisa ditinggalkan oleh tim pengabdian begitu saja tanpa pendampingan.

\section{UCAPAN TERIMA KASIH}

Penulis mengucapkan terima kasih kepada Kelurahan Kebonagung Kecamatan Mejayan dan LPPM Universitas PGRI Madiun untuk izin pelaksanaan. Terima kasih pula penulis haturkan kepada Dinas Lingkungan Hidup Kabupaten Madiun, Balai Pengelolaan DAS dan Hutan Lindung Solo, Bengkel Sapi Farm, Toko Robin, segenap masyarakat, khususnya Karang Taruna RT 10 Dusun Gonalan Desa Kebonagung Kecamatan Mejayan Kabupaten Madiun yang telah memberi donasi baik barang, uang maupun tenaga terhadap program ini.

\section{DAFTAR PUSTAKA}

Angelia, I. O. (2019). Merintis Desa Hijau Mandiri Melalui Program Kebun Bibit Masyarakat di Desa Panggulo Barat, Kecamatan Botupingge Kabupaten Bone Bolango, Provinsi Gorontalo. Jurnal Abdimas Gorontalo, 2(1), 29-34. 
Anonim. (2020). Permintaan Jamu Tradisional Meningkat. Media Indonesia. Retrieved February 13, 2021, from https://mediaindonesia.com/nusantara/294888/permintaanjamu-tradisional-meningkat.

Aziz, Y. M., Setiawan, N. M., \& Hikmawan, M. D. (2020). Aksi Masyarakat Peduli Sanitasi Dalam Mewujudkan Kampung Hijau Di Cempaka Putih, Jakarta Pusat. JSPG: Journal of Social Politics and Governance, 2(1), 73-87.

Ischak, M. \& Burhannudinnur, M. (2020). Upaya Meningkatkan Pengetahuan dan Kesadaran Masyarakat Tentang Pentingnya Ruang Terbuka Hijau di Permukiman Padat. Jurnal AKAL: Abdimas dan Kearifan Lokal, 1(1), 6-17.

Lidyana, V. (2020). Bisnis Tanaman Hias yang Makin Seksi di Tengah Pandemi. Detik Finance. Retrieved February 12, 2021, from https://finance.detik.com/berita-ekonomibisnis/d-5274145/bisnis-tanaman-hias-yang-makin-seksi-di-tengah-pandemi

Rizki Nurhana Friantini, Rahmat Winata, Pradipta Annurwanda, Siti Suprihatiningsih, Muhammad Firman Annur, Bernadeta Ritawati, \& Iren. (2020). PENGUATAN KONSEP MATEMATIKA DASAR PADA ANAK USIA SEKOLAH DASAR. Jurnal Abdimas Bina Bangsa, 1(2), 276-285. doi:10.46306/jabb.v1i2.55

Solikhah, A. \& Fatimah, T. (2020). Kampung Hijau pada Kampung Kota (Studi Kasus: Kampung Tanjung Gedong Rt.05/ Rw.08, Jakarta Barat). Jurnal Bakti Masyarakat Indonesia, 3(1), 137-147.

Wijaya Kusuma, J., Isnaini, Junedi, B., Nugroho, N., Meilisa, R., \& Jefri, U. (2020). SOSIALISASI DAN PENDAMPINGAN PENGISIAN SENSUS PENDUDUK 2020 ONLINE SERENTAK DI UNIVERSITAS BINA BANGSA. Jurnal Abdimas Bina Bangsa, 1(1), 48-54. doi:10.46306/jabb.v1i1.4

Yanizon, A. \& Rofiqah, T. (2018). Pemberdayaan Masyarakat dalam Mewujudkan Lingkungan Hijau (Green Land) Melalui Penanaman 1000 Pohon di Kavling Melati RW 06 Kelurahan Sungai Pelunggut. Minda Baharu, 2(2), 154-165. 